\title{
X-Linked Lymphoproliferative Disease: Twenty-Five Years after the Discovery
}

\author{
THOMAS A. SEEMAYER, THOMAS G. GROSS, R. MAARTEN EGELER, \\ SAMUEL J. PIRRUCCELLO, JACK R. DAVIS, CHRISTOPHER M. KELLY, MOTOHIKO OKANO, \\ ARPAD LANYI, AND JANOS SUMEGI \\ Departments of Pathology [T.A.S., T.G.G., S.J.P., J.R.D., C.M.K., A.L., J.S.] and Pediatrics \\ [T.A.S., T.G.G.], University of Nebraska Medical Center, Omaha, Nebraska 68198-3135, Department of \\ Pediatrics [R.M.E.], Sophia Children's Hospital, Rotterdam, The Netherlands, and Department of \\ Pediatrics [M.O.], Hokkaido University, Sapporo, Japan
}

\begin{abstract}
axis
The X-linked lymphoproliferative disease (XLP), one of six described X-linked immunodeficiencies, stems from a mutation at Xq25 which renders males impotent to mount an effective immune response to the ubiquitous EBV. Purtilo, who first observed this disease in 1969, established a Registry in 1980 to serve as a worldwide resource for the diagnosis, treatment, and research of this condition. Since Purtilo's death in late 1992, the Registry and research unit have not only continued to function as a worldwide consultative service, but have contributed the following. First, the number of affected boys has continued to grow; some 272 among 80 kindreds have been identified. Second, some boys $(10 \%)$ who inherit the mutated XLP gene are immunologically abnormal even before evidence of EBV exposure. Third, the search for the XLP gene has been narrowed to a small region on Xq25. Its identification is near at hand; once cloned, this gene may well illustrate how the body orchestrates the complex immune response to EBV. Therein lies the justification for the quest for this gene, not only for the benefit of the few surviving
\end{abstract}

boys and those to be born to female carriers, but also for defining its role in defending the body against a ubiquitous DNA virus.

(Pediatr Res 38: 471-478, 1995)

$\quad$ Abbreviations
EBNA, Epstein-Barr nuclear antigen
IFN, Interferon
IM, infectious mononucleosis
RFLP, restriction fragment length polymorphism
TH1, T-helper type 1
TH2, T-helper type 2
VAHS, virus-associated hemophagocytic syndrome
VCA, viral capsid antigen
XLA, X-linked agammaglobulinemia
XLHM, X-linked hypergammaglobulinemia M
XLP, X-linked lymphoproliferative disease
YAC, yeast artificial chromosome

\section{EVENTS LEADING TO THE RECOGNITION OF XLP}

This review traces the history of relevant events before and after the discovery of a disease of the immune system some $25 \mathrm{y}$ ago. What began as an astute observation at the autopsy table in 1969 is now the subject of intense molecular investigation in several laboratories across two continents. To some extent, the latter quest is an intellectual and technologic assault to disinter a gene, establish its sequence, determine its protein product, and, above all, define its normal function. Through the gifts of parents and friends, the William C. Havens Foundation was established to promote research into the pathogenesis, treatment, and ultimate resolution of XLP.

Correspondence and reprint requests: Thomas A. Seemayer, M.D., FRC Path, Department of Pathology and Micróbiology, University of Nebraska Medical Center, 600 South 42nd Street, Omaha NE 68198-3135.

Supported by the William C. Havens Foundation, Omaha, NE, and by the Lymphoproliferative Research Fund.
The recognition in 1969 and ultimate description of XLP in 1975 were made possible by a series of findings in the late 1950 s, 1960s, and early 1970 s which related to the EBV and immune dysfunction. These are briefly summarized.

The story begins with the description by Denis Burkitt in 1958 of an unusual, rapidly growing, and lethal sarcoma in children in Uganda and central Africa (1). Although the tumor featured a distinct predilection for extranodal sites, O'Conor established in 1961 that it was a lymphoma (2); thus, Burkitt's working in the United Kingdom, reported the successful cultivation of these malignant lymphoblasts (3) and demonstrated members of the Herpesvirus family, became known as the Epstein-Barr virus (EBV). lymphoma entered the literature. In 1964, Epstein and Barr, virus particles in the tumor (4). The virus, one of seven 
Not long thereafter, the Henle's, working in Philadelphia, made several interesting observations. First, EBV was capable of transforming "in vitro" normal peripheral blood lymphocytes into immortalized lymphoblastoid cell lines (5). Second, they confirmed the observation made months previously by Pope (6) that peripheral blood lymphocytes obtained from a patient (one of their technicians) with IM could be cultivated in vitro. Moreover, a small percentage of these cells contained EBV antigens, and postinfectious serum contained EBV antibodies, whereas preinfectious serum was devoid of such antibodies (7). This led to collaborative studies in New Haven which established firmly in 1968 that EBV was the etiologic agent of IM (8). The viral tropism for lymphocytes, specifically $B$ cells, was later shown to stem from a receptor closely related to the $\mathrm{C} 3 \mathrm{~d}$ component of complement for EBV on B lymphocytes (9).

As with man, EBV can infect and transform B lymphocytes "in vitro" from a New World non-human primate, the cottontopped marmoset $(10,11)$. Cell-free EBV, autologous transformed cells, or cell-associated virus given to these marmosets can induce fatal B cell lymphoproliferative states (12).

After the demonstration in 1970 that patients with nasopharyngeal carcinoma, a highly malignant neoplasm prevalent in certain parts of Asia, had elevated serologic titers of antibodies to EBV (13), it came as no surprise that EBV DNA was identified in the malignant epithelium of these neoplasms (14).

About this time, studies originating in the United States revealed that individuals with compromised immune systems, whether genetically determined (15) or iatrogenically induced (16), were subject to B cell lymphoproliferative malignancies. Only later would EBV be shown to be operative in these states (17-20) and in a newly defined lethal epidemic, AIDS (21).

\section{THE DISCOVERY OF XLP}

The definitive work, published in 1975 (22), stemmed from observations drawn over a 6-y period. The index case was defined in 1969 after an autopsy at Children's Hospital of Boston. The autopsy was performed under the supervision of one of the very best pediatric pathologists, the late Gordon F. Vawter, M.D. A previously healthy 8 -y-old boy died $30 \mathrm{~d}$ after the onset of IM with fulminant hepatitis and marrow failure. The liver, spleen, lymph nodes, and marrow were diffusely infiltrated with immunoblasts, plasma cells, and histiocytes. At the time, Dr. Vawter, despite his vast experience, was unable to cogently ascribe the clinical/autopsy findings to a lengthy list of uncommon pediatric conditions. Not long thereafter, it was learned that two brothers died in early life from an acute illness characterized by features which resembled IM and acute lymphoblastic leukemia. Subsequently, it was learned that three maternally related nephews developed agammaglobulinemia after IM, cerebral lymphoma after IM, and extranodal (ileocecal) lymphoma unrelated to IM. These boys, related to a common ancestor, surname Duncan, defined a new entity (Duncan's disease) characterized by a presumed X chromosomal mutation which places affected males in jeopardy when confronted by EBV. At the time, this clearly was disquieting news, as yet another condition was defined in which this ever-present virus might inflict human disease. The issue then centered upon defining more clearly the disease state in these affected boys, formulating treatment for the vulnerable and, above all, initiating research into its pathogenesis.

\section{THE CREATION OF THE XLP REGISTRY}

To track and characterize this disease, a Registry was established in 1980 (23). As computerization advanced, the literature was scoured to identify boys who had inherited what appeared to represent an inability to confront EBV. In due course, this led to a pursuit which covered vast corners of North America, Europe, the Middle East, South America, and Australia.

\section{THE NORMAL IMMUNE RESPONSE TO EBV}

Before discussing the clinical phenotypes of XLP, it shall be necessary to describe the normal immune response which contains this ubiquitous virus.

EBV replicates in the oropharyngeal cells (24), from which it is shed into the saliva (25). Infection generally follows exposure to infected saliva, although blood transfusions may also result in EBV infection (26). Given its tropism for B cells, the lymphoid tissue of Waldeyer's ring becomes infected, and the EBV-laden B cells disseminate widely. In most individuals, the immune system responds with silent efficiency, such that no overt clinical state is induced. Most of us produce lifelong IgG antibodies to EBV proteins (VCA and EBNA), a reflection of a steady-state between productive viral cycles and immune recognition, as well as the latent property of this Herpesvirus.

Through studies of patients with IM, the complexity and elegance of this immune response has been defined. At the moment of clinical malaise, lymphadenopathy, pharyngitis, splenic enlargement, and hepatic dysfunction, a consortium of immune elements is well engaged. Early on, natural killer cell and $\mathrm{CD} 4^{+} \mathrm{T}$ cell activity are heightened (27). At this time, cytokine production is underway and B cells undergo a polyclonal expansion and synthesize $\operatorname{IgM}$ and $\operatorname{IgG}$ antibodies to EBV-determined proteins. Later on, cytotoxic $\mathrm{CD}^{+} \mathrm{T}$ cells restricted to class I MHC antigens and specific for EBV undergo proliferative expansion to check the $\mathrm{B}$ cell infection (27). In due course, the immune response dominates and a "ceasefire" is drawn, commensurate with the regression of adenopathy and splenomegaly and return of hepatic homeostasis. As with quiescent seroconversion, low grade productive and lytic viral cycles are met with immune surveillance, as reflected by the sustained production of $\operatorname{IgG}$ antibodies to VCA and EBNA.

\section{CLINICAL PHENOTYPES OF XLP}

At this writing, the collected data of the XLP Registry have been totally reassessed and tabulated. Among some 80 families, 272 boys have been defined to have XLP and over 2,500 family members have been studied. The low numbers of affected boys suggest that the disease is rare. Although this is true, we suspect the condition is underdiagnosed and that the true incidence is greater than the Registry data would suggest. 
These data allow for a precise description of the diverse phenotypes of XLP (28-30). The most recent tabulation of the Registry is presented in Table 1.

Fulminant IM with VAHS. For XLP boys, their parents, and clinicians the most dramatic expression of XLP takes this form. In contrast to the well orchestrated normal immune response to $\mathrm{EBV}$, these boys mount a dysregulated, exuberant response to the virus, which unleashes $\mathrm{CD} 8^{+}$. T cells, EBVinfected B cells, and macrophages in tissues throughout the body. Through the effects of cytotoxic $T$ cells and other associated cytokines, extensive parenchymal damage ensues, most vividly manifest in the liver (as fulminant hepatitis) and bone marrow (as profound hypoplasia). Other tissues are also affected, as infiltrates and cell injury are manifest in the spleen (extensive necrosis of white pulp), brain (perivascular mononuclear cell infiltrates), heart (mild mononuclear cell myocarditis), kidneys (mild interstitial nephritis), and thymus. The latter features thymocyte depletion and necrosis of thymic epithelium (31), not unlike that seen in human (32) and experimental (33) graft-versus-host disease and in AIDS (34). The VAHS component features widely disseminated histiocytes replete with erythrocytes and nuclear debris. This element is present in $90 \%$ of boys fulminant IM. Nearly half of the XLP boys feature this phenotype; most die within 1 mo post-EBV infection. Until recently, no treatment was available.

Dysgammaglobulinemia. This expression of XLP most often, but not always, follows EBV infection. Affected patients have varying degrees of hypogammaglobulinemia primarily affecting IgG antibodies. Changes in $\operatorname{IgM}$ and $\operatorname{IgA}$ levels are also present, most commonly manifesting as hyper-IgM. The lymphoid tissues (lymph nodes, white pulp of spleen, thymus, bone marrow) are the site of extensive damage with resulting necrosis and lymphoid depletion. Lymph nodes may also feature extensive areas of calcification. Boys who survive this complication are treated (as those hypogammaglobulinemic pre-EBV infection) with monthly i.v. gammaglobulins.

Malignant lymphoma. This expression of XLP presents a new twist in the spectrum of genetically determined diseases associated with EBV infection. The lymphomas have been uniformly extranodal, most often affecting the ileocecal region (29). Lesser numbers of cases have been tabulated at central nervous system, hepatic, and renal sites (29). These lymphomas are usually of Burkitt's type, although four cases of Hodgkin's disease have occurred. Although most are of B cell origin, some have a $\mathrm{T}$ cell phenotype. In at least two cases, the characteristic 8;14 translocation in a Burkitt's lymphoma was found $(35,36)$. Clinicopathologic features of these lymphomas (extranodal predilection, high grade histology, clonality, gene rearrangement) are similar to those seen in other primary immunodeficiencies. In 18 patients, lymphoma developed without serologic evidence of previous EBV infection. Two of these cases went on to succumb to fatal IM years after cure of their lymphoma.

Aplastic anemia. Distinct from the marrow depletion attending fulminant IM with VAHS, a limited number of boys have developed isolated marrow aplasia (either pancytopenia or pure red cell aplasia) after EBV infection. Regrettably, little is known regarding the pathogenesis of this aplastic state, although it has been shown that nearly one-third of non-XLP patients with sporadic aplastic anemia have EBV in their marrow cells (37).

Vasculitis and pulmonary lymphomatoid granulomatosis. Several boys have developed lymphoid vasculitis resulting in destruction of arterial walls with ensuing aneurysmal dilatation (29). Five have presented with $\mathrm{T}$ cell pulmonary lymphomatoid granulomatosis (29). Four were EBV seronegative, and the EBV genome could not be detected in the lesions. One of the patients also manifested lymphomatoid granulomatosis of the central nervous system with extensive damage. Curiously, these lymphoproliferations represented primarily activation of $\mathrm{CD} 4^{+} \mathrm{T}$ cells and could occur in the absence of EBV exposure.

Sequential phenotypes. Not uncommonly, XLP boys manifest several phenotypes of the disease over time. This phenotypic variation most often includes dysgammaglobulinemia, malignant lymphoma and marrow aplasia. In contrast, most of those who develop IM and VAHS die within 1 mo of onset of symptoms; thus, this phenotype appears to be unique.

\section{PATIENT SURVIVAL}

Follow-up data are available for $87 \%$ of the boys. Seventyfive percent of the boys have died, some $70 \%$ before $10 \mathrm{y}$ of age; only two have lived to $40 \mathrm{y}$ of age. Of the 157 who have developed fulminant IM and VAHS, the most virulent phenotype of XLP, five have recently been successfully treated with chemotherapy, and four have received etoposide (VP-16), with or without immunosuppressive therapy, resulting in quiescent disease and survival. Survival rates for fulminant IM/VAHS, lymphoproliferative disorders, dysgammaglobulinemia, and aplastic anemia are $4,35,55$, and $50 \%$, respectively (Table 1 ).

\section{IMMUNODEFICIENCY PRIOR TO EBV EXPOSURE}

It was long suspected that XLP boys were immunodeficient even before EBV infection. Several boys developed measles

Table 1. Phenotypes of 272 XLP boys from 80 families as compiled from the XLP Registry

\begin{tabular}{|c|c|c|c|}
\hline Phenotype & Number affected & $\begin{array}{l}\text { Mean age at } \\
\text { onset (y) }\end{array}$ & Survival rate \\
\hline Fulminant IM & $157(58)^{*}$ & 5 & $5 / 132(4)^{*}$ \\
\hline $\begin{array}{l}\text { Lymphoproliferative disorders (includes five cases of T cell } \\
\text { lymphoproliferation and three cases of Hodgkin's disease) }\end{array}$ & $82(30)$ & 6 & $25 / 71$ \\
\hline Dysgammaglobulinemia & $84(31)$ & 9 & $41 / 74 \quad(55)$ \\
\hline Aplastic anemia & $8(3)$ & 8 & $4 / 8 \quad(50)$ \\
\hline Vasculitis, lymphomatoid granulomatosis & $7(3)$ & 6.5 & $2 / 7 \quad(29)$ \\
\hline
\end{tabular}

* Numbers in parentheses are percentages. 
pneumonitis, two incurred Neisseria meningitidis infection, and one succumbed to disseminated vaccinia after smallpox vaccination (29). From these anecdotal experiences, especially the latter, it was reasoned that these boys harbor an abnormal immune system before an encounter with EBV.

During the 1980s, extensive immunologic studies were performed in these boys, yet few patterns of immune dysfunction emerged. The most consistent defect related to an inability to switch Ig isotype ( $\operatorname{IgM} \rightarrow \operatorname{IgG}$ ) after consecutive exposures to phage $\phi X 174$ (38). Although not specific to XLP, for years this test represented the "gold standard" to identify boys who inherited the mutated gene. As well, the inability to mount an IgG response to EBNA after EBV infection appeared to represent a characteristic trait of the XLP boys, although these two defects may also be seen in other primary immunodeficiencies.

The DNA and serum obtained from the four corners of the world led to interesting data. Some 32 boys, devoid of serologic and, in some cases, genomic evidence for EBV infection, have been found through RFLP analysis to have inherited the mutated gene. Among these, 27 manifest an XLP phenotype: 17 dysgammaglobulinemia (either panhypogammaglobulinemia or hypo-IgG $\mathrm{Ig}_{1}$ and $\mathrm{IgG}_{3}$ and hyper-IgM with or without hyper-IgA) and 18 lymphoproliferative disease, including three of $\mathrm{T}$ cell origin (39). Thus, even in the absence of EBV infection, these boys feature an inability to regulate Ig gene expression and/or to contain $\mathrm{B}$ or $\mathrm{T}$ cell lymphoproliferation.

\section{THE DIAGNOSIS OF XLP}

Upon assuming charge of the Registry, we deemed it important to define the criteria for establishing the diagnosis of XLP. Objective elements involved family history, clinical findings, genotypic analyses, and serologic studies to quantitate Igs, EBNA antibodies after EBV infection, and assess for Ig isotype switch after exposure to phage $\phi \mathrm{X} 174$. These criteria, akin to those established decades ago for the diagnosis of acute rheumatic fever, were published in 1993 (30) and are presented in Table 2.

\section{DETECTION OF THE CARRIER STATE IN FEMALES}

As time passed, a critical and not insignificant issue centered about determining the carrier state of young women, usually sisters of XLP boys. Fortunately, this need coincided with progress in the genotypic detection of the disease state. Thus, since the early 1990s, females at risk have been genotyped using DNA probes and RFLP analyses to loci [DXS42, DXS37, and DXS12 (40) and, more recently, DXS10 and DXS100] near the XLP gene. In families in which the clinical criteria can be met and RFLP analysis is informative, a strong presumptive determination can be made regarding carrier status.

\section{THERAPY FOR XLP}

Until recently, treatment of XLP boys has been painfully disappointing. Antiviral agents such as acyclovir, IFN- $\gamma$ and $-\alpha$, and Ig administered at the onset of EBV infection have been ineffective. Empiric therapy with parenteral Ig rich in anti-EBV antibodies has been given to EBV-negative and -positive boys based on evidence that maternal antibodies protect the newborn infant from primary EBV infection for 4-6 mo. Even this is not absolute, because several boys have succumbed to fulminant EBV infection and others have become infected with EBV while under this putative Ig prophylaxis. Therefore, it is our current recommendation that Ig therapy is not necessary, except in the cases of dysgammaglobulinemia.

Initially, results in the treatment of malignant lymphoma of XLP were extremely poor. However, with current standard chemotherapy protocols for the treatment of pediatric lymphomas, remission is often achieved. These remissions can be durable, but relapse or development of other manifestations of XLP are nearly universal.

The use of etoposide (to quell macrophage activation) and/or $\mathrm{T}$ cell immunosuppression (cyclosporin $\mathrm{A}$ ) have been employed successfully in treating boys with severe acute IM/ VAHS or aplastic exacerbations of XLP; however, there is at least one case in which this approach was unsuccessful. Notwithstanding this setback, the use of etoposide is recommended, as one has but to read of the dramatic salvage of a young boy with severe acute IM and VAHS who responded to the drug. The acute symptoms were quenched, and, in due course, he underwent successful bone marrow transplantation (41).

Currently, the only curative therapy is allogeneic hematopoietic stem cell transplantation $(36,41,42)$. Some eight affected male patients have undergone stem cell transplantation (six sibling marrow donors, one unrelated marrow donor, one

Table 2. Criteria for establishing a diagnosis of XLP

\begin{tabular}{cc}
\hline Diagnosis of XLP & Criteria \\
\hline $\begin{array}{l}\text { Definitive diagnosis of XLP } \\
\text { Probable diagnosis of XLP:* } \\
\text { Major criteria }\end{array}$ & Two or more maternally-related males manifest an XLP phenotype following EBV infection \\
& Strong genetic linkage to the XLP locus in male with informative markers; XLP phenotype in male after \\
EBV infection & \\
Hinor criteria & Eyperimmunoglobulinemia A or M (before EBV infection); hypoimmunoglobulinema G1 or G3 (before \\
& EBV infection); inadequate anti-Epstein-Barr nuclear antigen Ig response after EBV infection; failure to \\
undergo IgM $\rightarrow$ IgG switch after secondary challenge with $\phi X 174$ & Any male maternally related to a male manifesting XLP phenotype \\
\hline
\end{tabular}

* Diagnosis requires both major criteria or one major and two minor criteria.

Published with permission of the American Medical Association. This table was originally published in The American Journal of Diseases of Children 147:1242-1245, 1993, and is copyright 1993, American Medical Association. 
umbilical cord blood from sibling). Age at time of transplant appears to be critical; all four boys less than age 15 are alive and well $2 \mathrm{y}$ or more post-transplant, whereas all four greater than $15 \mathrm{y}$ of age died within $90 \mathrm{~d}$ of complications of transplantation (Gross TG, unpublished observations).

\section{THE X CHROMOSOME AND IMMUNODEFICIENCY}

It is now apparent that the $\mathrm{X}$ chromosome is a major repository of genes vital to immune function. This reasoning stems from the fact that most immunodeficiencies are X-linked and/or autosomal recessive. Thus, males are clearly at a heightened risk to inherit mutated genes central to thwarting infectious agents. This led to the concept that there exists an immunologic basis for the superior survival of females (43).

As things stand, some six conditions stemming from mutant genes have been defined. Five of these genes have been cloned; four relate to lymphocytes and one involves neutrophils. In all instances, the functional properties of the affected cells are subverted and severe disease, often fatal, is the outcome.

The first condition, chronic granulomatous disease, may present in both an X-linked and an autosomal recessive form. As for the former, the responsible gene, which encodes for cytochrome B in neutrophils, normally enables these scavengers to release superoxides in response to bacterial infections. This gene was found to be mutant in those boys who incur recurrent bacterial and fungal infections (44).

In 1993 and 1994, four additional X-linked genes relating to immunodeficiency were cloned.

In X-linked agammaglobulinemia, the mutated gene, ATK (adenosine tyrosine kinase), a member of the src family of oncogenes, prevents affected boys from expressing a particular intracellular tyrosine kinase in their B cells which is developmentally regulated and required for B cell differentiation (45). $B$ cell maturation is therefore halted at the pre-B cell stage, thereby leading to a block in the synthesis of all Ig, resulting in recurrent episodes of pyogenic infections.

In the condition known as hypergammaglobulinemia $\mathrm{M}, \mathrm{Ig}$ isotype switching is blocked, resulting in the production, generally excessive, of $\operatorname{IgM}$ and $\operatorname{IgD}$, yet very low or absent levels of IgG, IgA, and IgE. The process of isotype switching involves several signals, one of which is the binding of a tumor necrosis factor-related activator protein (TRAP) on T cells to the CD40 ligand on B cells. Mutation of the TRAP gene constitutes the molecular basis for the failure in isotype switching (46), manifesting clinically by recurrent bacterial infections and pathologically by the absence of germinal centers in lymphoid tissues.

In the X-linked form (autosomal recessive forms also exist) of severe combined immunodeficiency, the quintessential immune deficiency, mutation of the gene encoding the $\gamma$ chain of IL-2 receptor constitutes the molecular basis of the inability to generate normally functioning mature T cells (47). Since this $\gamma$ chain is shared by the IL- 7 and IL- 4 receptors, the defect results in an inability to respond to IL-2, IL-4, and IL-7. In these patients, the B cells produced are akin to neonatal B cells and Ig production may be impaired. Failure to thrive, diarrhea, and recurrent, ultimately fatal, viral/fungal/parasitic infections stem from this mutation.

In Wiskott-Aldrich syndrome, boys suffer from severe eczema, thrombocytopenia, and recurrent pyogenic, viral, and protozoan infections. Circulating leukocytes have a defective expression of sialophorin, a CD43 transmembrane mucin-like molecule (48) necessary for cell-cell contacts and $\mathrm{T}$ cell and monocyte activation. Because the gene for sialophorin resides on $16 \mathrm{p}$, this $\mathrm{CD} 43$ abnormality cannot represent the sole molecular defect in this condition. Indeed, the gene for Wiskott-Aldrich syndrome, which was mapped to Xp11.2211.3, has been recently cloned and found to encode for a 501-amino acid protein pivotal to lymphocyte and platelet function (49).

The final X-linked immunodeficiency condition is XLP. As discussed subsequently, neither the molecular basis for the disease nor the identity of the gene is as yet known.

The locations of the genes responsible for these X-linked conditions are illustrated in Figure 1.

\section{THE SEARCH FOR THE GENE IN XLP}

The inheritance pattern of XLP allowed an instant assignment of the gene to the $\mathrm{X}$ chromosome, narrowing its position from anywhere in $3000 \mathrm{Mb}$, which is the size of the human genome, to $150 \mathrm{Mb}$, the size of the human X chromosome.

Skare et al. (50) provisionally mapped the gene responsible for XLP to the long arm of the X chromosome between Xq24 and Xq26. In 1989, the same group narrowed down the critical region of the XLP gene to approximately $15 \mathrm{Mb}$ around DXS42 and DXS37, using restriction fragment length polymorphisms $(51,52)$. Although most of the affected individuals show no structural defect of the X chromosome, Wyandt et al. found one family (Registry \#43) with partial deletion of Xq25-26 accompanying XLP $(53,54)$.

Subsequently, much progress has been made in the genetic mapping of the XLP gene in Xq25. Prior study of seven kindreds linked the XLP gene to DXS42 (LOD 17.5) and DXS37 (LOD 13.3) (52). In the genetic map, DXS37 is proximal (centromeric) to DXS42. Physical mapping indicated that DNA markers DXS42 and DXS37 were present in the index XLP family with the interstitial deletion. However, the marker loci for DXS6, DXS739, and DXS100 were absent in the male patient (Registry \#43-004) with the Xq25 deletion. Three overlapping deletions found in Skare's laboratory soon thereafter established the gene locus and refined its location to a 2.5-Mb region in Xq25 (55).

To be able to construct a physical map of the XLP critical region, several YAC clones have been isolated carrying DNA sequences deleted in the $\mathrm{X}$ chromosome of Registry patient \#43-004. DNA probes from the region specific YAC in combination with DNA markers with known locations were used to establish a physical map of the region using interphase fluorescence in situ hybridization (56). The authors suggested the following order in the region: cen-(DXS12, DXS42)-DXS6DXS982-DXS739-DXS75-DXS100-DXS10-DXS177-tel. Using DNA probes from the region, additional XLP patients with interstitial deletions were identified by Skare et al. (55) and in 


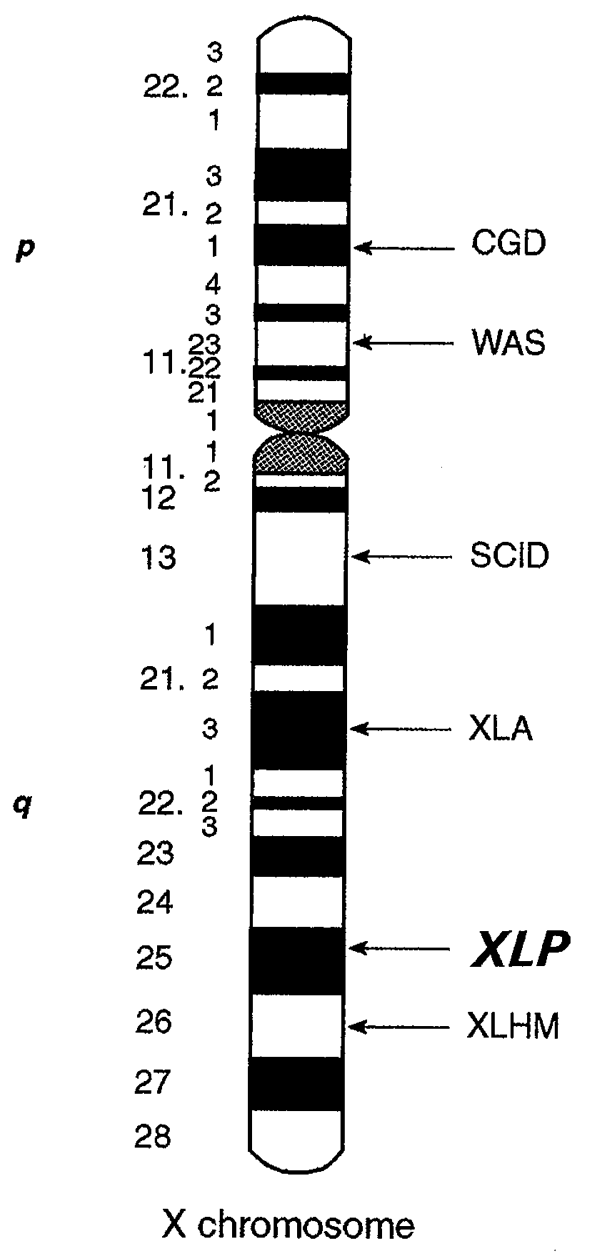

Figure 1. Schematic representation of the $X$ chromosome, depicting six loci central to immune function. Each of these genes, except for XLP (indicated in italics), has been cloned. Abbreviations: $\mathrm{CGD}=$ chronic granulomatous disease, SCID = severe combined immunodeficiency, WAS $=$ WiskottAldrich syndrome, XLA $=\mathrm{X}$-linked agammaglobulinemia, XLHM $=\mathrm{X}$ linked hypergammaglobulinemia $\mathrm{M}, \mathrm{XLP}=\mathrm{X}$-linked lymphoproliferative disease. This schematic is published with permission of Mosby-Year Book Publishing Company, Philadelphia, PA, as it shall appear in Chapter 27, "Primary Immunodeficiencies," of the forthcoming 10th edition of Anderson's Textbook of Pathology (I. Damjanov and J. Linder, eds). The figure was designed by the medical illustrator, Ms. Mary Jean McFadden, and is copyright 1995, Mosby-Year Book Publishing Company.

our own laboratory (Sumegi J, unpublished). It was concluded that the XLP candidate gene region spans the region between DXS6 and DXS100 and corresponds to approximately $2 \mathrm{Mb}$ of DNA. This region has been completely covered by overlapping YAC clones (Sumegi $J$, unpublished); hence, it is but a matter of time before the gene is cloned.

\section{HYPOTHESIS}

Recently, it has been recognized that the immune response to infection is regulated by a balance between the TH1 and $\mathrm{TH} 2$ cell responses. The phenotypes of the specific cells responsible for these divergent responses have not been discerned. However, TH1 responses are characterized by the secretion of cytokines (e.g. IL-2 and IFN- $\gamma$ ) and are responsible for cell-mediated immune responses. $\mathrm{TH} 2$ responses are characterized by the secretion of cytokines (e.g. IL-4 and
IL-10) required in an humoral immune response $(57,58)$. In addition, these two types of responses counterbalance each other (i.e. TH2 down-regulates TH1 and vice versa).

The predominant type of response (TH1 versus TH2) has been shown to have clinical significance in various types of infections. Infections with intracellular organisms are less severe when the TH1 response predominates. For example, people infected with Mycobacterium leprae can display a spectrum of clinical manifestations. In tuberculoid leprosy, which features local lesions, the TH1 response predominates, but in disseminated disease, lepromatous leprosy, the $\mathrm{TH} 2$ response is predominant $(59,60)$. Similar results have been shown in infections with Mycobacterium tuberculosis (60-62) and leishmania $(58,60,63)$. However, in extracellular infections (e.g. helminth parasitic infections), the $\mathrm{TH} 2$ response is associated with less severe disease $(60,64)$.

We suspect, because EBV is an intracellular infection, that the TH1 response is important in the initial control of the infection. IFN- $\gamma$ has been shown to be elevated in the serum of a patient following primary infection; however, it was only detectable during the incubation period and not when symptoms of acute IM developed (65). This suggests that the TH1 response may be important in controlling the early infection, but is normally downregulated, probably by the $\mathrm{TH} 2$ response, resulting in persistent humoral immunity, as is normally observed. In contrast, in three out of five XLP patients with fatal IM, elevated levels of IFN- $\gamma$ were detected (66). Characteristically, XLP patients who survive primary infection do not mount an appropriate humoral response to $\mathrm{EBV}$ (i.e. low titers and/or absent antibodies to EBNA) $(19,29,67)$.

It is our hypothesis that the defect in XLP resides in the inability to effect an appropriate $\mathrm{TH} 2$ response after infection with EBV. As a result, the TH1 response is uncontrolled, devoid of regulation, and either leads to parenchymal dysfunction (fatal IM) or results in dysgammaglobulinemia, aplastic anemia and dysregulation of other immune functions (natural killer and cytotoxic $\mathrm{T}$ cell activity) predisposing to lymphoma.

\section{CONCLUDING REMARKS}

The XLP story portrays an interesting chapter in medical science. The disease, initially discovered at the autopsy table, is now the subject of hot pursuit in the molecular laboratory. The XLP Registry data reveal that the mutated gene renders boys vulnerable to dysimmunoregulation and lymphoproliferative lesions, some before and all after EBV infection. Given the near universal infection of man by the virus, there are compelling reasons to pursue the quest of this gene, to establish its structure and, above all, to determine its function.

Acknowledgments. The excellent editorial assistance of Darryl C. Burgdorf in the preparation of this manuscript is gratefully acknowledged. Equally important, we wish to extend heartfelt appreciation to Karen Spiegel, who, for years, has been the devoted Registrar of the XLP Registry. Lastly, we wish to express our indebtedness to the late David T. Purtilo, who, in his own way, greatly enriched our lives. David discovered XLP at the autopsy table in 1969 and then devoted his 
considerable strengths toward the elucidation of its pathogenesis and treatment over the next 22 years. The DNA he obtained from affected boys shall make possible the cloning of the gene, either by us or others with whom he generously shared material. On his death in 1992, he had assembled a group to carry forth his mission. In may ways, this is his story, if not his legacy.

\section{REFERENCES}

1. Burkitt D 1958 A sarcoma involving the jaws in African children. Br J Surg 46:218-223

2. O'Conor GT 1961 Malignant lymphoma in African children. II. A pathological entity. Cancer 14:270-283

3. Epstein MA, Barr YM 1964 Cultivation in vitro of human lymphoblasts from Burkitt's malignant lymphoma. Lancet 1:252-253

4. Epstein MA, Achong BG, Barr YM 1964 Virus particles in cultured lymphoblasts from Burkitt's lymphoma. Lancet 1:702-703

5. Henle W, DiehI V, Kohn G, zur Hausen H, Henle G 1967 Herpes-type virus and chromosome marker in normal leukocytes after growth with irradiated Burkitt cells. Science 157:1064-1065

6. Pope JH 1967 Establishment of cell lines from peripheral leucocytes in infectious mononucleosis. Nature 216:810-811

7. Henle G, Henle W, Diehl V 1968 Relation of Burkitt's tumor-associated herpes-type virus to infectious mononucleosis. Proc Natl Acad Sci USA 59:94-101

8. Niederman JC, McCollum RW, Henle G, Henle W 1968 Infectious mononucleosis: Clinical manifestations in relation to EB virus antibodies. JAMA 203:205-209

9. Jondal M, Klein G, Oldstone MBA, Bokish V, Yefenof E 1976 Surface markers on human $\mathrm{B}$ and $\mathrm{T}$ lymphocytes. VIII. Association between complement and EpsteinBarr virus receptors on human lymphoid cells. Scand J Immunol 5:401-410

10. Falk L, Wolfe L, Deinhardt F, Paciga J, Dombros L, Klein G, Henle W, Henle G 1974 Epstein-Barr virus: Transformation of nonhuman primate lymphocytes in vitro. Int J Cancer 13:363-376

11. Frank A, Andiman WA, Miller G 1976 Epstein-Barr virus and nonhuman primates: Natural and experimental infection. Adv Cancer Res 23:171-201

12. Miller G, Shope T, Coope D, Waters L, Pagano J, Bornkamm GW, Henle W 1977 Lymphoma in cotton-topped marmosets after inoculation with Epstein-Barr virus: tumor incidence, histologic spectrum, antibody responses, demonstration of viral DNA, and characterization of viruses. J Exp Med 145:948-967

13. Henle W, Henle H, Ho H-C, Burtin P, Cachin Y, Clifford P, de Schryver A, de-Thé G, Diehl V, Klein G 1970 Antibodies to Epstein-Barr virus in nasopharyngea carcinoma, other head and neck neoplasms and control groups. J Natl Cancer Inst 44:225-231

14. zur Hausen $H$, Schulte-Holthausen $H$, Klein G, Henle W, Henle G, Clifford P, Santesson L 1970 EBV DNA in biopsies of Burkitt's tumors and anaplastic carcinoma of the nasopharynx. Nature 228:1056-1058

15. Gatti RA, Good RA 1971 Occurrence of malignancy in immunodeficiency diseases: a literature review. Cancer 28:89-98

16. Penn I, Hammond W, Brettschneider L, Starzl TE 1969 Malignant lymphomas in transplantation patients. Transplant Proc 1:106-112

17. Hanto DW, Frizzera G, Gajl-Peczalska KJ, Purtilo DT, Klein G, Simmons RL, Najarian JS 1981 The Epstein-Barr virus (EBV) in the pathogenesis of post-transplant lymphoma. Surgery 90:204-213

18. Shearer WT, Ritz J, Finegold M, Guerra IC, Rosenblatt HM, Lewis DE, Pollack MS, Taber LH, Sumaya CV, Grumet FC, Cleary ML, Warnke R, Sklar J 1985 EpsteinBarr virus-associated B-cell proliferations of diverse clonal origins after bone marrow transplantation in a 12 -year-old patient with severe combined immunodeficiency. $\mathrm{N}$ Engl J Med 312:1151-1159

19. Okano N, Thiele GM, Davis JR, Grierson H, Purtilo DT 1988 Epstein-Barr virus and human diseases: recent advances in diagnosis. Clin Microbiol Rev 1:300-312

20. Purtilo DT, Strobaugh RS, Okano M, Davis JR 1992 Biology of disease: Epstein-Barr virus-associated lymphoproliferative disorders. Lab Invest 67:5-23

21. Borisch-Chappuis B, Müller H, Stutle J, Hey MM, Hübner K, Müller-Hermelink HK 1990 Identification of EBV-DNA in lymph nodes from patients with lymphadenopathy and lymphomas associated with AIDS. Virchows Arch B Cell Pathol 58:199205

22. Purtilo DT, Cassel CK, Yang JPS, Harper P, Stephenson SR, Landing BH, Vawter GF 1975 X-linked recessive progressive combined variable immunodeficiency (Duncan's disease). Lancet 1:935-941

23. Hamilton JK, Paquin LA, Sullivan JL, Maurer HS, Cruzi PG, Provisor AJ, Steuber CP, Hawkins E, Yawn D, Cornet J, Clausen K, Finkelstein GZ, Landing B, Grunnet M, Purtilo DT 1980 X-linked lymphoproliferative syndrome registry report. J Pediatr 96:669-673

24. Sixbey JW, Nedrud JG, Raab-Traub N, Hanes RA, Pagano JS 1984 Epstein-Barr virus replication in oropharyngeal epithelial cells. N Engl J Med 310:1225-1230

25. Miller G, Niederman JC, Andrews L-L 1973 Prolonged oropharyngeal excretion of Epstein-Barr virus after infectious mononucleosis. N Engl J Med 288:229-232

26. Gerber P, Purcell RH, Rosenblum EN, Walsh JH 1969 Association of EB-virus infection with the post-perfusion syndrome. Lancet 1:593-596

27. Liebowitz D 1995 Epstein-Barr virus: an old dog with new tricks. N Engl J Med 332:55-57
28. Purtilo DT, Grierson HL 1989 Epstein-Barr virus-induced immune deficiency. In: Specter S, Bendinelli M, Friedman H (eds) Virus-Induced Immunosuppression. Plenum Publishing, New York, pp 125-140

29. Purtilo DT, Grierson HL, Davis JR, Okano M 1991 The X-linked lymphoproliferative disease: From autopsy toward cloning the gene, 1975-1990. Pediatr Pathol 11:685-710

30. Seemayer TA, Grierson H, Pirruccello SJ, Gross TG, Weisenberger DD, Davis J Spiegel K, Brichacek B, Sumegi J 1993 X-linked lymphoproliferative disease. Am J Dis Child 147:1242-1245

31. Mroczek EC, Seemayer TA, Grierson HL, Markin R, Linder J, Brichacek B, Purtilo DT 1987 Thymic lesions in fatal infectious mononucleosis. Clin Immunol Immunopathol 43:243-255

32. Seemayer TA, Bolande RP 1980 Thymic involution mimicking thymic dysplasia, a consequence of transfusion-induced graft-versus-host disease in a premature infant. Arch Pathol Lab Med 104:141-144

33. Seemayer TA, Lapp WS, Bolande RP 1977 Thymic involution in murine graft-versus host reaction: Epithelial injury mimicking human dysplasia. Am J Pathol 88:119-134

34. Seemayer TA, Laroche AC, Russo P, Malebranche R, Arnoux E, Guerin JM, Pierre G, Dupuy JM, Gartner JG, Lapp WS, Spira TA, Elie R 1984 Precocious thymic involution manifest by epithelial injury in the acquired immune deficiency syndrome. Hum Pathol 15:469-474

35. Egeler RM, de Kraker J, Slater R, Purtilo DT 1992 Documentation of Burkitt's lymphoma with $t(8 ; 14)(q 24 ; q 23)$ in $X$-linked lymphoproliferative disease. Cancer 70:683-687

36. Williams LL, Rooney CM, Conley ME, Brenner MK, Krance RA, Heslop HE 1993 Correction of Duncan's syndrome by allogeneic bone marrow transplantation. Lancet 2:587-588

37. Baranski B, Armstrong G, Truman JT, Quinnan GV Jr, Straus SE, Young NS 1989 Epstein-Barr virus in the bone marrow of patients with aplastic anemia. Ann Intern Med 109:695-704

38. Ochs HD, Sullivan JL, Wedgwood RJ, Seeley JK, Sakamoto K, Purtilo DT 1983 $\mathrm{X}$-linked lymphoproliferative syndrome: abnormal antibody responses to bacteriophage $\phi X 174$. Birth Defects 19:321-323

39. Gross TG, Patton DF, Davis JR, Sumegi J, Pirruccello SJ, Kelly CM and Seemaye TA 1994 X-linked lymphoproliferative disease (XLP) manifested without apparent EBV infection (abstract). The VII International Conference on the Epstein-Barr Virus and Associated Diseases, Cold Spring Harbor, NY

40. Purtilo DT, Grierson HL 1991 Methods of detection of new families with X-linked lymphoproliferative disease. Cancer Genet Cytogenet 51:143-153

41. Pracher E, Panzer-Grümayer ER, Zoubek A, Peters C, Gadner H 1994 Successful bone marrow transplantation in a boy with X-linked lymphoproliferative syndrome and acute severe infectious mononucleosis. Bone Marrow Transplant 13:655-658

42. Vowels MR, Lam-Po-Tang R, Berdoukas V, Ford D, Thierry D, Purtilo D, Gluckman E 1993 Brief report: Correction of X-linked lymphoproliferative disease by transplantation of cord-blood stem cells. N Engl J Med 329:1623-1625

43. Purtilo DT, Sullivan JL 1979 Immunological bases for superior survival in females. Am J Dis Child 133:1251-1253

44. Royer-Pokora B, Kunkel LM, Monaco AP, Goff SC, Newburger PE, Baehner RL, Cole FS, Curnutte JT, Orkin SH 1986 Cloning the gene for an inherited human disorder-chronic granulomatous disease-on the basis of its chromosomal location. Nature 322:32-38

45. Vetrie D, Vorechovsky I, Sideras P, Holland J, Davies A, Flinter F, Hammarström L Kinnon C, Levinsky R, Bobrow M, Smith CIE, Bentley DR 1993 The gene involved in X-linked agammaglobulinaemia is a member of the $\operatorname{src}$ family of protein-tyrosine kinases. Nature 361:226-233

46. Korthäuer U, Graf D, Mages HW, Brière F, Padayachee M, Malcolm S, Ugazio AG, Notarangelo LD, Levinsky RJ, Kroczek RA 1993 Defective expression of T-cell CD40 ligand causes X-linked immunodeficiency with hyper-IgM. Nature 361:539543

47. Noguchi M, Yi H, Rosenblatt HM, Filipovich AH, Adelstein S, Modi WS, McBride OW, Leonard WJ 1993 Interleukin-2 receptor $\gamma$ chain mutation results in X-linked severe combined immunodeficiency in humans. Cell 73:147-157

48. Remold-O'Donnell E, Rosen FS 1990 Sialopharin (CD43) and the Wiskott-Aldrich syndrome. Immunodef Rev 2:151-174

49. Derry JMJ, Ochs HD, Francke U 1994 Isolation of a novel gene mutated in Wiskott-Aldrich syndrome. Cell 78:635-644

50. Skare J, Milunsky A, Byron KS, Sullivan J 1987 Mapping the X-linked lymphoproliferative syndrome. Proc Nat Acad Sci USA 84:2015-2018

51. Skare J, Sullivan J, Milunsky A 1989 Mapping the mutation causing the X-linked lymphoproliferative syndrome in relation to restriction fragment length polymorphisms on Xq. Hum Genet 82:349-353

52. Skare J, Grierson H, Sullivan J, Nussbaum RL, Purtilo DT, Sylla B, Lenoir G, Reilly DS, White BN, Milunsky A 1989 Linkage analysis of seven kindreds with the $\mathrm{X}$-linked lymphoproliferative syndrome (XLP) confirms that the XLP locus is near DXS42 and DXS37. Hum Genet 82:354-358

53. Wyandt H, Grierson H, Sanger W, Skare J, Milunsky A, Purtilo DT 1989 Chromosome deletion of $\mathrm{Xq} 25$ in an individual with $\mathrm{X}$-linked lymphoproliferative disease. Am J Med Genet 33:426-430

54. Sanger W, Grierson H, Skare J, Wyandt H, Pirruccello S, Fordyce R, Purtilo DT 1990 Partial Xq25 deletion in a family with the X-linked lymphoproliferative disease (XLP). Cancer Genet Cytogenet 47:163-169

55. Skare J, Wu B-L, Madan S, Pulijaal V, Purtilo DT, Haber D, Nelson D, Sylla B, Grierson H, Nitowsky H 1993 Characterization of three overlapping deletions causing X-linked lymphoproliferative disease. Genomics 16:254-255

56. Wu B-L, Milunsky A, Nelson D, Schmeekpeper B, Porta G, Schlessinger D, Skare J 1993 High-resolution mapping of probes near the X-linked lymphoproliferative disease (XLP) locus. Genomics 17:163-170 
57. Mosmann TR, Cherwinski H, Bond MW, Ciedlin MA, Coffman RL 1986 Two types of murine helper $\mathrm{T}$ cell clones. I. Definition according to profiles of lymphokine activities and secreted proteins. J Immunol 136:2348-2357

58. Scott P 1993 Selective differentiation of CD4+ T helper cell subsets. Curr Opinion Immunol 5:391-397

59. Yamamura M, Uyemura K, Deans RJ, Weinberg K, Rea TH, Bloom BR, Modlin RL 1991 Defining protective responses to pathogens: Cytokine profiles in leprosy lesions. Science 254:277-279

60. Modlin RL, Nutman TB 1993 Type 2 cytokines and negative immune regulation in human infections. Curr Opinion Immunol 5:511-517

61. Bloom WH, Wallis RS, Chervenak KA 1991 Human mycobacterium tuberculosisreactive $\mathrm{CD} 4+\mathrm{T}$-cell clones: heterogeneity in antigen recognition, cytokine production and cytotoxicity for mononuclear phagocytes. Infect Immun 59:2737-2743

62. Barns PF, Abrams JS, Lu SZ, Seiling PA, Rea TH, Modlin RL 1993 Patterns of cytokine production by mycobacterium-reactive human T-cell clones. Infect Immun 61:197-203
63. Pirmez C, Yamamura M, Uyemura K, Paes-Oliveira M, Conceicao-Silva F, Modlin RL 1991 Cytokine patterns in the pathogenesis of human leishmaniasis. J Clin Invest 91:1390-1395

64. Mahanty S, Abrams JS, King CL, Limaye AP, Nutman TB 1992 Parallel regulation of IL-4 and IL-5 in human helminth infections. J Immunol 148:3567-3571

65. Svedmyr E, Ennberg I, Seeley J, Weiland O, Masucci G, Tsukuda K, Szigeti R, Masucci MG, Blomgren H, Berthold W, Henle W, Klein G 1984 Virologic, immunologic, and clinical observations on a patient during the incubation, acute, and convalescent phases of infectious mononucleosis. Clin Immunol Immunopathol convalescent

66. Okano M, Thiele GM, Purtilo DT 1993 Variable presence of circulating cytokines in patients with sporadic or X-linked lymphoproliferative disease with fatal infectious mononucleosis. Pediatr Hematol Oncol 10:97-99

67. Purtilo DT 1991 X-linked lymphoproliferative disease (XLP) as a model of EpsteinBarr virus-induced immunopathology. Springer Semin Immunopathol 3:181-197 